\title{
Phosphate - The Silent Stealthy Cardiorenal Culprit in All Stages of Chronic Kidney Disease
}

\section{A Systematic Review}

\author{
Mehmet Kanbay ${ }^{a}$ David Goldsmith ${ }^{b} \quad$ Ali Akcay $^{a} \quad$ Adrian Covic $^{c}$ \\ ${ }^{a}$ Department of Internal Medicine, Section of Nephrology, Fatih University School of Medicine, Istanbul, Turkey; \\ ${ }^{b}$ Department of Internal Medicine, Renal Unit, Guy's Hospital, London, UK; ' Nephrology Clinic, Dialysis and Renal \\ Transplant Center, 'C.I. PARHON' University Hospital, 'Gr. T. Popa' University of Medicine and Pharmacy, \\ lasi, Romania
}

\section{Key Words}

Cardiovascular disease $\cdot$ Cardiac mortality ·

Hyperphosphatemia $\cdot$ Kidney disease $\cdot$ Phosphate

\begin{abstract}
Background and Aim: Due to increasing evidence suggesting a link between hyperphosphatemia and cardiovascular disease (CVD), mediated through vascular calcification in patients on dialysis, the following question arises: At what stage of chronic kidney disease (CKD) does the relationship between elevated phosphate levels, vascular calcification and increased cardiovascular mortality begin? Therefore, the purpose of the current study was to critically review the current literature regarding this issue. Methods: We performed a systematic search of the National Library of Medicine and the Cochrane Library databases from January 1985 to February 2008 to identify clinical studies examining the effects of plasma phosphate on cardiovascular outcome, mortality and progression of kidney disease in subjects with and without CKD who have not yet received dialysis. The primary outcome measure was the development of CVD, mortality and progression of kidney disease. Results: Twelve clinical trials investigated the role of serum phosphate levels and adverse outcome ( 9 studies examining CVD outcome
\end{abstract}

and 3 examining progression of kidney disease). After adjustment for risk factors for mortality, adverse cardiovascular outcome and progression of kidney disease, all studies found a graded independent significant association between phosphate levels and mortality, development of CVD and progression of kidney disease. There was no such association with plasma calcium levels. Conclusions: There is a graded independent association between serum phosphate levels and mortality, mainly cardiovascular events, and the progression of renal disease in subjects with and without definable (loss of glomerular filtration rate) CKD.

Copyright $\odot 2009$ S. Karger AG, Basel

\section{Introduction}

Cardiovascular disease (CVD) is the leading cause of mortality and morbidity in patients with chronic kidney disease (CKD) before dialysis is needed, in patients on dialysis programs or even in patients after successful renal transplantation. At any age, patients on dialysis more frequently succumb to cardiovascular death compared to age- and gender-matched non-CKD patients, with $>50 \%$ of all deaths due to CV events [1]. This is by no means as simple as, for example, an increased prevalence of coro-

\section{KARGER}

Fax +4161306 1234 E-Mail karger@karger.ch www.karger.com
(C) 2009 S. Karger AG, Basel

0253-5068/09/0272-0220\$26.00/0

Accessible online at:

www.karger.com/bpu
Mehmet Kanbay, MD

Gokkusagi Mahallesi, 16. Cadde, No. 16/21

TR-06490 Cevizlidere/Cankaya, Ankara (Turkey)

Tel. +90 50526688 66, Fax +90 3124415498

E-Mailmkanbay@fatih.edu.tr or drkanbay@yahoo.com 
nary artery disease (CAD); while it is true that $40-70 \%$ of patients receiving dialysis have clinically evident CAD, this alone is not a sufficient explanation for either the rate or the modality of mortality seen $[2,3]$. Sudden (cardiac) death, heart failure, and coronary and valvular heart disease are all additional important factors $[1,2]$. Depressingly little interventional success in reducing mortality rates on renal replacement therapy has thus far been demonstrable, despite many trials and 4 decades of clinical dialytic therapy $[3,4]$.

Explanations for this worryingly higher rate of CVD and mortality are numerous and include a high prevalence of traditional risk factors (particularly hypertension and diabetes mellitus $[5,6])$ as well as the presence of numerous other, non-traditional risk factors. Clinical and epidemiological studies have consistently suggested an important role for vascular calcifications (particularly linked to both CAD and arterial stiffening) in the pathogenesis of 'uremic' CVD and as an elevated risk for increased morbidity and mortality in patients with endstage renal disease $[7,8]$.

From a pathophysiological point of view, experimental studies have clearly demonstrated that higher phosphate levels induce a phenotypic transformation of vascular smooth muscle cells into osteoblast-like cells (calcifying vascular cells), which ultimately cause vascular calcification in the vessel wall media and intima [9]. Moreover, recent clinical studies have shown that higher serum phosphate levels are strongly associated with vascular calcification and cardiovascular mortality among people who receive chronic dialysis [10-15]. Block et al. [10] described, although in a post hoc analysis of a prospective trial, a direct relationship between hyperphosphatemia and mortality in dialysis patients. Patients with serum phosphate levels $>6.5 \mathrm{mg} / \mathrm{dl}(2.15 \mathrm{mmol} / \mathrm{l})$ had a $27 \%$ higher risk of death after adjustment for other traditional and non-traditional confounding risk factors [10]. Hence elevation of serum phosphate levels - already dubbed a 'silent killer' of dialysis patients - should be considered to be an integral target for the routine care of chronic dialysis patients [16].

The increasing recognition and acceptance of a link between hyperphosphatemia and CVD, mediated through vascular calcification in patients on dialysis, of necessity then prompts a further question: At what stage of CKD does this relationship between elevated phosphate, vascular calcification and increased cardiovascular mortality begin? To answer this important question, we will need to examine the evidence that exists in patients not yet receiving dialysis, including patients with only the mildest manifestations of CKD. This last point is of paramount potential importance given recent epidemiological observations that $13 \%$ of the US population have some degree of CKD [17].

The purpose of the current study was therefore to critically review the current literature on the effects of plasma phosphate on adverse cardiovascular outcome, mortality and progression of kidney disease in subjects with and without CKD but not yet on dialysis. This first such systematic review was conducted in a structured manner, including a review of the methodology, outcomes and limitations of each constituent study.

\section{Methods}

\section{Search Strategy}

We systematically searched Medline and the Cochrane Database, with no language restrictions, for studies in humans on the association between serum phosphate level and mortality, development of CVD [including myocardial infarction (MI), congestive heart failure (CHF) and stroke], hypertension, vascular calcification and progression of kidney disease published between January 1985 and February 2008. The key words phosphate, phosphorus, mortality, cardiovascular disease, myocardial infarction and renal function with their synonyms and equivalent Medical Subject Heading terms were used. The searches were performed in coordination with an information specialist, and the abstracts and the articles were assessed by a member of the research team. We scrutinized the reference lists of the identified reports, reviews, meta-analyses, other relevant publications and the 'related articles' function in Medline to find additional pertinent studies.

\section{Selection Criteria}

We included randomized controlled trials, cohort studies and case-control studies if they investigated the association between phosphate and adverse outcome including CVD, mortality, progression of renal disease and atherosclerosis, defined as a primary or secondary outcome measure; studies were accepted only if they included subjects not on dialysis. The eligibility of each study was assessed independently by two investigators (M.K. and A.A.).

\section{Data Extraction and Quality Assessment}

Reports from all eligible studies were evaluated for appropriateness for inclusion without prior consideration of results. We used information about: study design, patient characteristics, risk estimates and their 95\% confidence interval (CI, either with serum phosphate level quartile or expressed as a slope per incremental serum phosphate level increase [standardized to $1 \mathrm{mg} / \mathrm{dl}$ $(0.32 \mathrm{mmol} / \mathrm{l})$ increments)].

Quality assessment was performed by two independent reviewers (M.K. and A.A.), and in case of any uncertainties the relevant studies were discussed with other team members. Data were assessed for blinding outcome assessment, quality of adjustment analyses including age, gender, glomerular filtration rate (GFR) and other major potential confounders. Reviewers assessed study 
Table 1. Characteristics, results and limitations of the studies

\begin{tabular}{|c|c|c|c|c|c|c|c|}
\hline References & $\begin{array}{l}\text { Clinical } \\
\text { setting }\end{array}$ & $\begin{array}{l}\text { subjects } \\
\mathrm{n}\end{array}$ & $\begin{array}{l}\text { mean age } \\
\text { years }\end{array}$ & $\begin{array}{l}\text { diabetes } \\
\%\end{array}$ & $\begin{array}{l}\text { CVD } \\
\%\end{array}$ & $\begin{array}{l}\text { eGFR } \\
\mathrm{ml} / \mathrm{min} / 1.73 \mathrm{~m}^{2}\end{array}$ & $\begin{array}{l}\text { mean serum } \\
\text { phosphate, } \mathrm{mg} / \mathrm{dl}\end{array}$ \\
\hline $\begin{array}{l}\text { Narang } \\
\text { et al. [19] }\end{array}$ & patients with angina & 376 & 59 & 18 & 67 & NR & $3.6 \pm 0.6$ \\
\hline
\end{tabular}

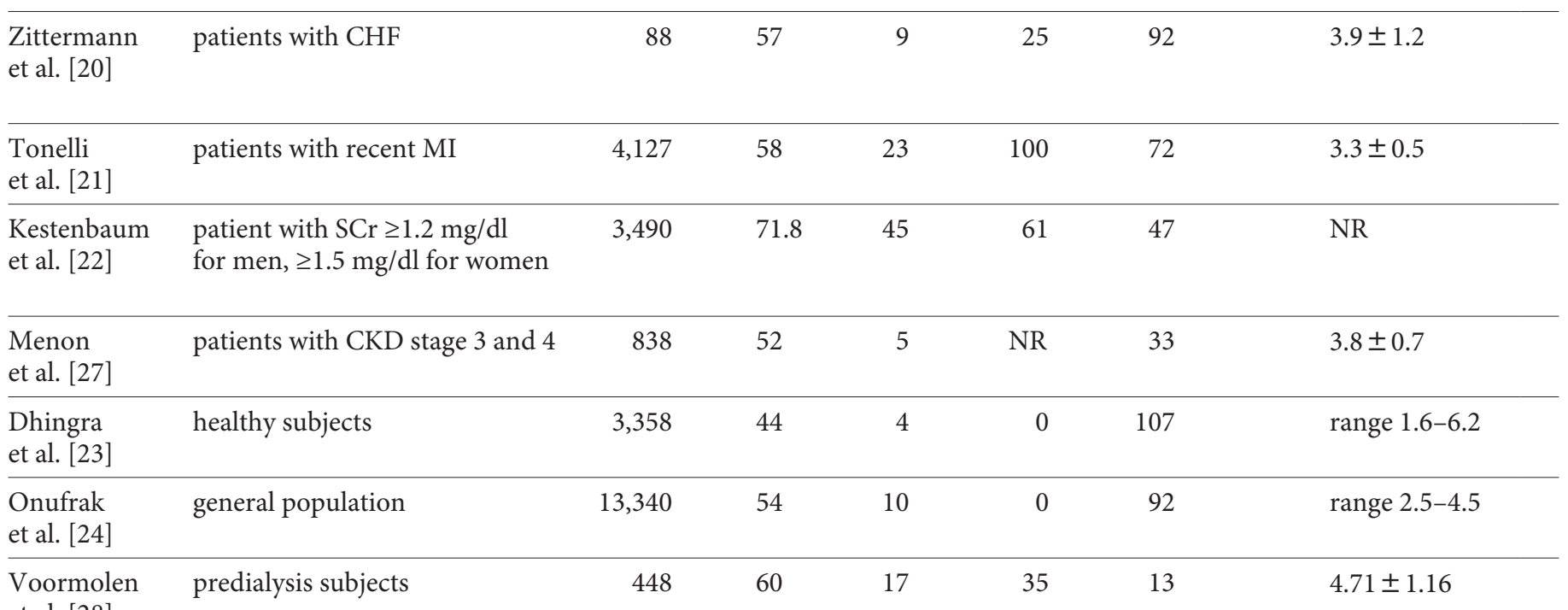

et al. [28]

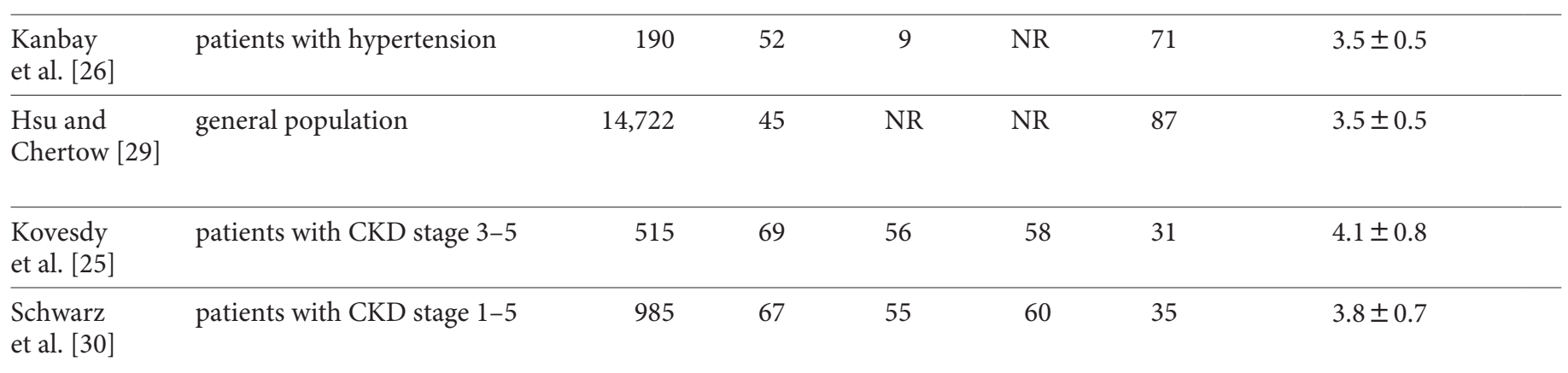

$\mathrm{NR}=$ Not reported.; $\mathrm{SCr}=$ serum creatinine; vitD = vitamin D.

quality according to guidelines outlined by Hayden et al. [18]. We assessed whether each study possessed the following six characteristics: (1) study sample represents the population of interest; (2) loss to follow-up is not associated with key characteristics and is minimized sufficiently to limit potential bias; (3) the prognostic factor of interest is adequately measured in study participants to sufficiently limit potential bias; (4) outcomes of interest are ade- quately measured in study participants; (5) important potential confounders are appropriately accounted for, and (6) statistical analyses are appropriate for the study design. Studies were graded as good quality if they met five to six criteria, fair if they met three to four criteria, and poor if they met two or fewer criteria. Quality of data adjustment analyses included age, gender, GFR and other major potential confounders, too. 
PTH and vitD not measured kidney function not reported included only patients with CAD; hence this study does not reflect the general population since the patients' SCr/GFR was not reported, the prevalence of renal dysfunction is not known

included only patients with normal kidney function $\Rightarrow$ relationship between $\mathrm{CHF}$ and phosphate remains unknown in CKD patients not on dialysis

PTH and vitD not measured
not representative of the general population
study population predominantly male and older
PTH and vitD not measured
mortality might be due to the severity of CKD
PTH and vitD not measured

PTH and vitD not measured mortality might be due to the severity of CKD

PTH and vitD not measured

PTH and vitD not measured

only advanced-stage renal disease included vitD levels and protein intake not measured

vitD not measured

protein intake not measured

study population predominantly male only advanced-stage renal disease included

study population exclusively male protein intake not measured $\mathrm{PTH}$ and vitD not measured independent positive association between phosphate level good and severity of CAD
CHF patients had higher phosphate levels

than controls

a graded independent significant association between phosphate levels and mortality

higher phosphate level strongly correlated with mortality good

$1 \mathrm{mg} / \mathrm{dl}$ increase in the phosphate level associated with a $10 \%$ higher risk of death higher phosphate levels are associated with an increased good CVD risk in subjects without CKD and CVD serum phosphate level positively associated with cIMT good

higher phosphate level is an independent risk factor for a

good rapid decline in kidney function mortality risk is 1.25 for each $1 \mathrm{mg} / \mathrm{dl}$ increase in the phosphate level during the predialysis period

independent relationship between higher phosphate levels fair and the risk of a decrease in nocturnal systolic $\mathrm{BP}<10 \%$

a higher serum phosphate level might also be a risk factor good for the development of hyperparathyroidism and CKD progression secondary hyperparathyroidism and high phosphate levels are independently associated with mortality

higher serum phosphate level might be a risk factor for CKD progression

good

good

good 


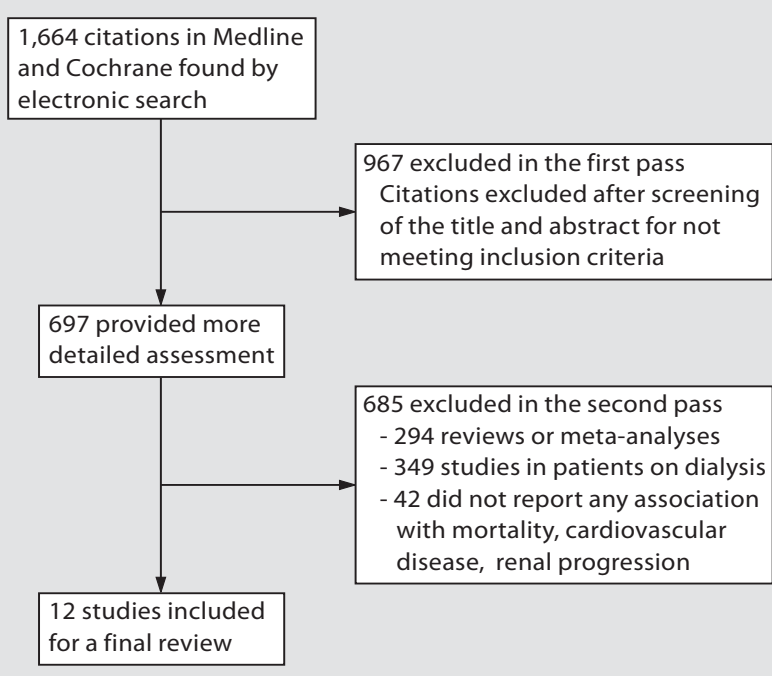

Fig. 1. Flow diagram of the study selection process.

\section{Results}

\section{Search Results}

Of 1,664 citations, 12 trials were eligible for inclusion. Figure 1 shows our search and selection process. Table 1 summarizes the characteristics, limitations and results of the studies. Seven studies included subjects with GFR $>60 \mathrm{ml} / \mathrm{min} / 1.73 \mathrm{~m}^{2}$ and five studies subjects with GFR $<60 \mathrm{ml} / \mathrm{min} / 1.73 \mathrm{~m}^{2}$.

\section{Results of Studies on Phosphate Levels, Mortality and $C V D$}

There were nine studies that investigated the relationship between serum phosphate levels and mortality overall or CV mortality rates (fig. 2a). The majority of the studies showed that a higher serum phosphate level was an independent risk factor for mortality and CVD even in patients with GFR $>60 \mathrm{ml} / \mathrm{min} / 1.73 \mathrm{~m}^{2}$ (fig. 2 b).

Narang et al. [19] investigated 376 patients with stable angina to evaluate the relation of serum calcium and phosphate levels with angiographic severity of luminal coronary artery stenosis. In this retrospective study, patients with known kidney disorders were not included in the analysis. On multiple regression analysis, serum phosphate was independently associated with the number of coronary vessels affected. Moreover, a higher serum phosphate level was significantly associated with the presence of total or subtotal occlusion and with more se- vere vessel stenosis. The odds ratios (OR) for significant angiographic disease were $1.25,1.73$ and 3.01 for every $0.3(0.09 \mathrm{mmol} / \mathrm{l}), 0.8(0.25 \mathrm{mmol} / \mathrm{l})$ and $1.5 \mathrm{mg} / \mathrm{dl}(0.5$ $\mathrm{mmol} / \mathrm{l}$ ) increase in serum phosphate levels, respectively. On the other hand, serum calcium levels were not independently associated with the severity of stenosis. Zitterman et al. [20] studied 54 patients with CHF and 34 participants without CHF. They excluded patients with serum creatinine $>2 \mathrm{mg} / \mathrm{dl}$ and those receiving supple mental vitamin $\mathrm{D}$. The majority of patients had nearnormal kidney function (GFR $>60 \mathrm{ml} / \mathrm{min} / 1.73 \mathrm{~m}^{2}$ ), estimated using the Cockcroft-Gault formula. They found that patients with CHF had higher phosphate, lower 25hydroxycalciferol and higher parathyroid hormone (PTH) levels compared to the control group.

Tonelli et al. [21] investigated the role of phosphate in CVD in a subpopulation of the CARE trial (a randomized pravastatin trial that included 4,127 participants) with a recent acute MI, normal kidney function (GFR $>60 \mathrm{ml} /$ $\mathrm{min} / 1.73 \mathrm{~m}^{2}$ ), estimated by the equation of the Modification of Diet in Renal Disease (MDRD), and a median follow-up duration of 60 months. Serum baseline phosphate levels were within normal laboratory range in $94.2 \%$ of the participants and were similar in subjects with and without GFR $<60 \mathrm{ml} / \mathrm{min} / 1.73 \mathrm{~m}^{2}$. Serum phosphate levels positively correlated with female gender, black race, current smoking status, diabetes mellitus status, systolic blood pressure and serum albumin, and inversely correlated with GFR. After adjustment for age, race and gender, serum phosphate was significantly associated with death, development of new heart failure and fatal/nonfatal MI: for each $1 \mathrm{mg} / \mathrm{dl}(0.32 \mathrm{mmol} / \mathrm{l})$ increase in serum phosphate the hazard ratios (HR) were: $1.22,95 \% \mathrm{CI}=$ $0.95-1.58$; $1.20,95 \% \mathrm{CI}=0.96-1.50$; and $1.22,95 \% \mathrm{CI}=$ $0.95-1.58$, respectively).

Kestenbaum et al. [22] examined 3,490 veterans to investigate the association between higher serum phosphate level and increased risk of mortality in patients with CKD. Higher phosphate levels correlated with younger age, diabetes mellitus, lower GFR and lower hemoglobin levels. The median follow-up time was 2.1 years. A $1 \mathrm{mg} / \mathrm{dl}(0.32 \mathrm{mmol} / \mathrm{l})$ increase in the serum phosphate level was associated with a $23 \%$ increase in risk for death (95\% CI $=1.12-1.36)$ after adjustment for age, renal function, race, comorbid conditions, gender and hemoglobin. Moreover, they also showed a linear relationship between phosphate and mortality for each 0.5 $\mathrm{mg} / \mathrm{dl}(0.16 \mathrm{mmol} / \mathrm{l})$ increment in the serum phosphate level, with the highest mortality being observed in patients with a serum phosphate $>3.5 \mathrm{mg} / \mathrm{dl}(1.12 \mathrm{mmol} / \mathrm{l})$. 


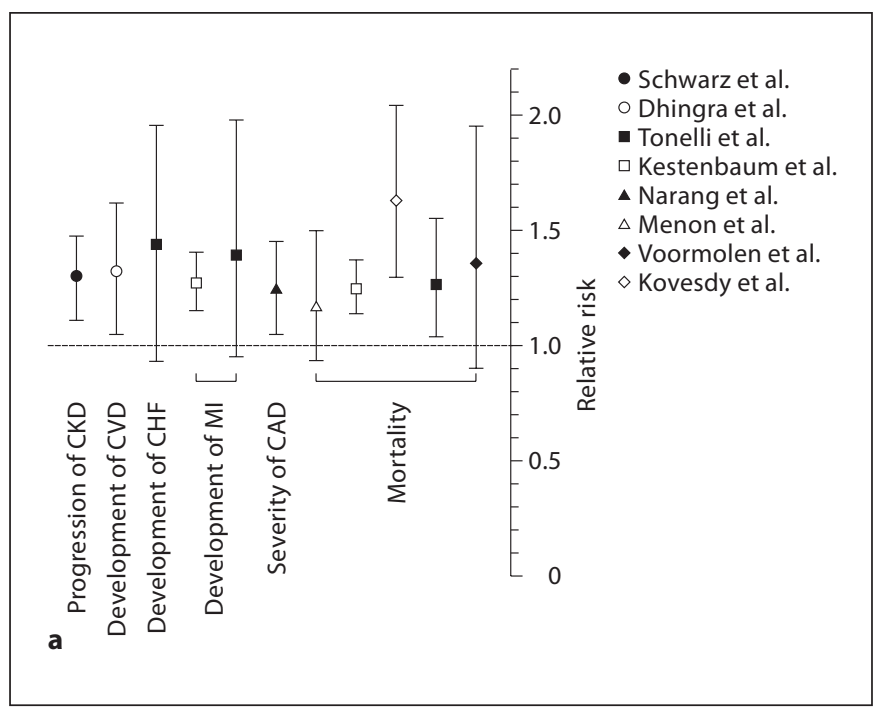

Fig. 2. Association between serum phosphate levels and mortality, severity of CAD, development of MI, CHF and CVD and CKD progression for $1 \mathrm{mg} / \mathrm{dl}$ increases in the serum phosphate level

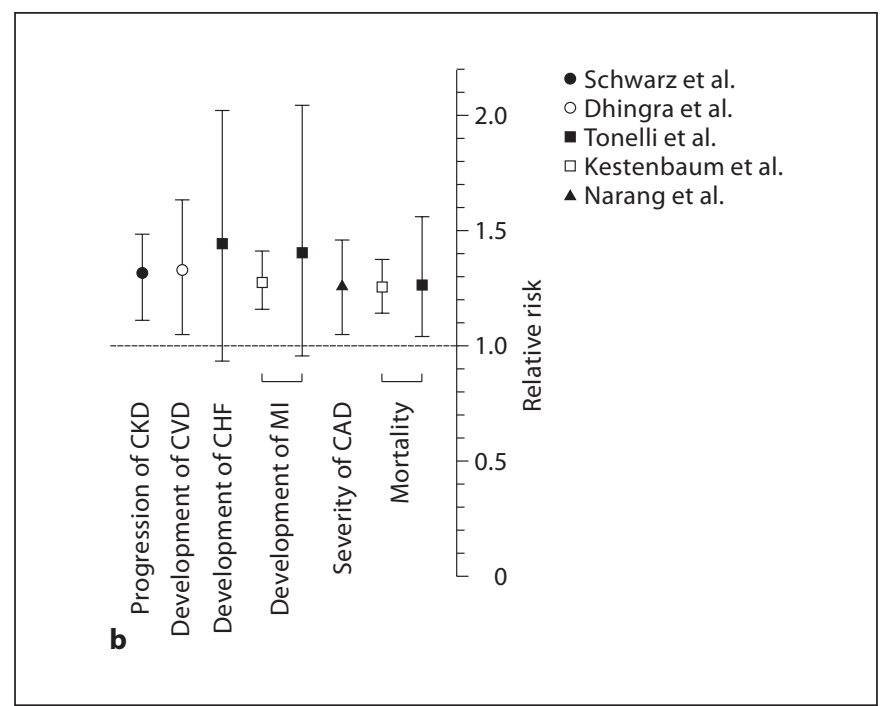

with the risk of each outcome in patients with and without CKD (a) and in patients with GFR $>60 \mathrm{ml} / \mathrm{min} / 1.73 \mathrm{~m}^{2}$ (b). CI and relative risks are shown for each association.
Interestingly, the strong association between higher phosphate levels and mortality was still present even if phosphate levels were within the normal range, and this association was independent of kidney function and other traditional and non-traditional confounding factors. Dhingra et al. [23] examined 3,368 individuals from the Framingham Offspring study. The mean follow-up duration was 16.1 years. The MDRD equation was used to derive estimated GFR (eGFR). Subjects with preexisting CVD and CKD $\left(e G F R<60 \mathrm{ml} / \mathrm{min} / 1.73 \mathrm{~m}^{2}\right)$ were not included in the main analysis. In multivariate analyses, serum phosphorus levels positively correlated with age, high-sensitivity C-reactive protein, eGFR, serum albumin levels and the total/HDL cholesterol ratio, and inversely correlated with body mass index and systolic blood pressure. A multivariate regression analysis adjusted for age and gender showed that the incidence of CVD (a combination of angina, MI, stroke, peripheral arterial disease and $\mathrm{CHF}$ ) increased across quartiles of serum phosphorus levels in a continuous fashion, but not across serum calcium level quartiles. This relationship was still observed in participants with eGFR $>90 \mathrm{ml} / \mathrm{min} / 1.73 \mathrm{~m}^{2}$ and without proteinuria. After adjusting for all CVD confounding factors, the HR for incident CVD relative to a $1 \mathrm{mg} / \mathrm{dl}(0.32 \mathrm{mmol} / \mathrm{l})$ increase in the serum phosphate level was 1.31 (95\% CI, 0.96-1.44, $\mathrm{p}=0.02)$. Serum calcium levels were not related to incident CVD.

Phosphate and Chronic Kidney Disease
Onufrak et al. [24] examined 13,340 participants of the ARIC study to investigate the association between phosphate and subclinical atherosclerosis in a sample of the general population. The MDRD equation was used to calculate eGFR. Carotid intima-media thickness (cIMT) measurements were obtained in all participants. Patients with previous heart disease or stroke were excluded. The majority of the participants' serum phosphorus was within the normal range (97\%). Greater phosphorus levels were noted with increased age, higher fibrinogen levels, diabetes mellitus, female sex, smoking and hypercholesterolemia. There was no association between eGFR and serum phosphate levels. After adjustment for age, eGFR and several other traditional risk factors, a statistically significant trend toward greater cIMT with increasing phosphorus quintiles was seen in men. The association was still present even in participants with normal eGFR (eGFR $>90 \mathrm{ml} / \mathrm{min} / 1.73 \mathrm{~m}^{2}$ ). By contrast, the serum calcium level was not associated with increasing cIMT.

Kovesdy et al. [25] examined 515 predialysis CKD stage 3-5 (mean eGFR $=31 \pm 11 \mathrm{ml} / \mathrm{min} / 1.73 \mathrm{~m}^{2}$ ) patients to investigate the role of hyperparathyroidism and hyperphosphatemia on outcome (including all-cause mortality and initiation of maintenance dialysis). The median follow-up was 2.3 years. Hyperparathyroidism (iPTH $>65 \mathrm{pg} / \mathrm{ml}$ ) and hyperphosphatemia $(>4 \mathrm{mg} / \mathrm{dl}$ or 
$>1.28 \mathrm{mmol} / \mathrm{l}$ ) were independently associated with mortality. The mortality risk during the dialysis period for each $1 \mathrm{mg} / \mathrm{dl}$ increase in the serum phosphate level was 1.65 (95\% CI, 1.30-2.09).

A recent study by Kanbay et al. [26] examined 190 hypertensive subjects with normal phosphate and PTH levels, GFR $>60 \mathrm{ml} / \mathrm{min}$ and no history of calcium, phosphate and vitamin $\mathrm{D}$ medication as well as hyperparathyroidism to investigate if higher serum phosphate, calcium or PTH levels and the calcium $\times$ phosphate product $(\mathrm{Ca}$ $\times \mathrm{P}$ ) were associated with a 'nondipper' hypertension profile (a nocturnal systolic blood pressure decrease $<10 \%)$ in patients with normal renal function and without any PTH disorder. Nondipper patients had significantly higher phosphate, $\mathrm{PTH}$ and $\mathrm{Ca} \times \mathrm{P}$ product levels than dipper patients. They observed a graded independent relationship between higher levels of phosphate $(\beta=$ $0.9, \mathrm{p}=0.03)$ and PTH $(\beta=0.43, \mathrm{p}=0.001)$, and the risk of nondipping, which is a major risk factor for adverse cardiovascular outcomes [26]. This may also explain the adverse outcome of patients with higher phosphate levels and mortality even in patients with normal kidney function.

Not all studies reported a statistically significant relationship between phosphorus and outcomes. Menon et al. [27] examined $838 \mathrm{CKD}$ patients in stage 3-4 participating in the randomized MDRD study. Serum phosphate levels were positively correlated with lower age, female sex, African-American race, lower eGFR and higher proteinuria. The median follow-up was 123 months. After adjustment for demographics, protein diet assignment, traditional cardiac risk factors, proteinuria and eGFR, each $1 \mathrm{mg} / \mathrm{dl}(0.32 \mathrm{mmol} / \mathrm{l})$ increase in the serum phosphate level was associated with a $10 \%$ higher risk of death (HR 1.10, 95\% CI $=0.86-1.40)$, and a $27 \%$ higher risk of cardiovascular death (HR 1.27, 95\% CI $=0.94-$ 1.73), but neither of these associations was statistically significant. In the recent multicenter, retrospective PREPARE study by Voormolen et al. [28], 448 predialysis patients at CKD stage 4-5 between 1999 and 2001 were followed up until 2003 or death. After correction for baseline eGFR, higher plasma phosphate was associated with higher $\mathrm{PTH}$, increased proteinuria, younger age, and the presence of glomerulonephritis or polycystic kidney disease. However, after adjustment for risk factors for mortality, the mortality risk for each $1 \mathrm{mg} / \mathrm{dl}(0.32$ $\mathrm{mmol} / \mathrm{l}$ ) increase in the phosphate level was non-significant at $1.62(95 \% \mathrm{CI}, 1.02-2.59)$ [28].

\section{Results of Studies on Phosphate Levels and CKD Progression}

There are three studies investigating the role of the serum phosphate level as a prognosticator of CKD progression (table 1).

Hsu and Chertow [29] analyzed the Third National Health and Nutrition Examination Survey (NHANES III; 1988-1994) data on 14,722 adults to evaluate the relationship between serum levels of phosphate and calcium, and renal function. Half of the participants were men and the mean age was 47 years. The mean GFR (CockcroftGault) was $87 \mathrm{ml} / \mathrm{min}$. Subtle elevations in serum phosphate might also be a risk factor for the development of hyperparathyroidism and the progression of CKD.

In the PREPARE study, a higher plasma phosphate level was independently associated with a more rapid decline in renal function even when the rate of decline was adjusted for known risk factors $(\beta=0.178,95 \% \mathrm{CI}=$ $0.082-0.275)$. Moreover, the analysis of patients with available PTH measurements showed that there was no association between the PTH level and the rate of decline in renal function [26].

Schwarz et al. [30] examined 985 male CKD veterans to investigate the association between the serum phosphate level and the progression of CKD. In this retrospective study, patients were followed up until death, the initiation of renal replacement therapy or doubling of the serum creatinine level. Median duration of follow-up was 2.1 years. After adjustment for age, race, systolic/diastolic blood pressure, diabetes, smoking status, eGFR, serum albumin, serum calcium, bicarbonate, hemoglobin, proteinuria and use of calcium-containing phosphate binders, a statistically significant trend towards higher CKD progression related to increasing phosphorus quintiles was observed. Patients with a baseline serum phosphate level $>4.3 \mathrm{mg} / \mathrm{dl}$ (>1.37 mmol/l) had the highest HR for the composite endpoint including doubling of serum creatinine and initiation of dialysis. A $1 \mathrm{mg} / \mathrm{dl}(0.32 \mathrm{mmol} / \mathrm{l})$ increase in the serum phosphate level was associated with an adjusted HR of 1.29 (95\% CI $=1.12-1.48, \mathrm{p}<0.001)$.

\section{Discussion}

This systematic review indicates that there is a graded, independent association between the serum phosphate level and mortality (mainly cardiovascular death), and between the serum phosphate level and progression of renal disease in subjects with and without definable CKD. Importantly, there is little or no evidence in these patient 
Fig. 3. Possible mechanisms between phosphate and CVD.

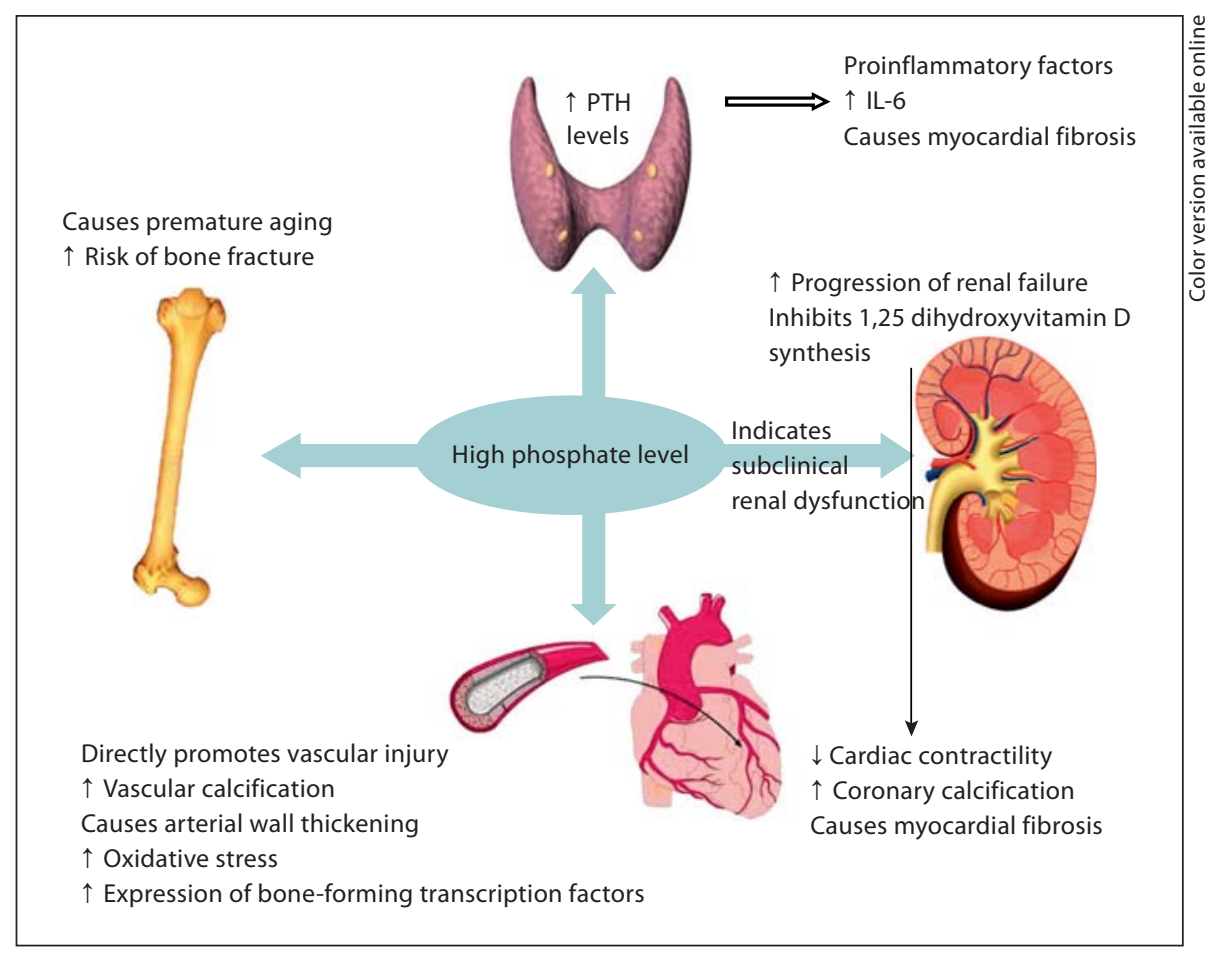

populations for a similar relationship with plasma calcium levels, which is a cardinal and important difference to the findings for patients on dialysis [11].

In health, the serum level of phosphate is tightly regulated by gastrointestinal and renal control of intake and excretion, and this regulation is achieved mainly by vitamin D, PTH and fibroblast growth factor 23 (FGF-23) [31-33].

The mechanism underlying the association between serum phosphate levels and adverse clinical outcomes have not been clarified yet. Several plausible mechanisms might explain the relationship between higher phosphate levels and CVD in patients not on dialysis (fig. 3).

\section{Phosphate and Adverse Cardiovascular Outcome \\ Experimental Evidence}

Higher phosphate levels may directly induce vascular injury by directly increasing vascular calcification and may enhance the tendency of mineral deposition in the vascular wall and the expression of bone-forming transcription factors and proteins $[9,34,35]$. An experimental study by Jono et al. [9] showed that phosphate may be able to transform vascular smooth muscle cells into calcifying cells by a direct mechanism involving the phosphate cotransporter Pit-1. Giachelli et al. [36] showed that phosphate induces the expression of bone makers and miner- alization of extracellular matrix. The bone proteins, including osteonectin, osteopontin, bone sialoprotein, type I collagen and alkaline phosphatase, have also been identified in extraskeletal calcification. In cell culture, vascular smooth muscle cells and vascular pericytes are able to produce these same bone-forming transcription factors and proteins at levels of $4.3 \mathrm{mg} / \mathrm{dl}(1.37 \mathrm{mmol} / \mathrm{l})$, which is within the normal laboratory range, and hyperphosphatemia can induce the secretion of these proteins [36]. Moreover, other animal studies showed that hyperphosphatemia after a high-phosphate diet is associated with myocardial hypertrophy and aggravates cardiac fibrosis and arterial wall thickening $[37,38]$. Experimental studies showed that a high PTH level causes intracellular calcium overload, cardiac fibrosis and impaired myocardial energy production in kidney failure [39]. High PTH levels may act as a proinflammatory cytokine and increase the production of interlekin-6, which is also a risk factor for CVD, via bone resorption or by hepatic synthesis [40, 41]. Both klotho and FGF-23 have recently been identified as premature aging-related genes. Klotho is a pleiotrophic transmembrane protein and has been identified as antiaging factor [42]. FGF-23 is a phosphaturic factor that is produced in bone and is a potent inhibitor of renal phosphate reabsorption [43]. These two multifunctional proteins regulate calcium-phosphate metabolism as well as 
aging, and deletion studies have shown that they also have a role in vascular calcification [42, 44]. In an experimental study, correction of hyperphosphatemia and high vitamin D levels ameliorated the premature aginglike phenotype in klotho knockout mice and in FGF-23 knockout mice $[43,45,46]$. One other possible mechanism might be hyperphosphatemia-induced oxidative stress. Yamamoto et al. [47] demonstrated that higher extracellular phosphate levels increase the production of reactive oxygen species in bovine aortic species. Fat and animal protein, which also independently increase the risk of cardiovascular events, are rich for phosphorus. Chan et al. [48] showed that a highly atherogenic diet caused hyperphosphatemia and hypercalcemia in rabbits, along with calcium-phosphate deposits in the aortic tissue, in addition to fibrofatty aortic plaques. Hence, control of phosphate levels may prevent aging-related disease, may thus increase the lifespan, decrease vascular calcification and slow down the progression of kidney disease.

\section{Clinical Evidence}

High serum phosphate levels may inhibit 1,25 dihydroxy vitamin D synthesis [49]. Vitamin D deficiency decreases cardiac contractility through the effects on intracellular calcium and phosphate levels, may play a role in the pathogenesis and development of CHF, and increases the risk of $\mathrm{MI}$ in the general population and coronary artery calcification [20, 49-52]. Moreover, some case reports stated that patients with untreated rickets or osteomalacia suffered from heart failure at younger age [51]. However, high phosphate levels might be a sign of subclinical renal dysfunction; consequently, the degree of the renal dysfunction rather than phosphate levels per se might account for the apparent association between higher serum phosphate and adverse clinical outcomes. Nevertheless, even in healthy individuals, higher phosphate levels directly increase parathyroid cell proliferation and the secretion of PTH - which has been associated with adverse cardiovascular outcomes in both abnormal and normal renal function [53]. Nishida et al. [54] performed a randomized, double-blind, crossover study in 8 healthy male volunteers with normal kidney function. They showed that after ingestion of a meal containing 400 $1,200 \mathrm{mg}$ of phosphate, plasma phosphate levels increased within $1 \mathrm{~h}$ and were elevated for $6 \mathrm{~h}$ after the meal. The results of this study suggest that postprandial hyperphosphatemia, due to over-intake of dietary phosphorus, might be an insidious risk factor for CVD and mortality, even in individuals without kidney dysfunction. This as- pect of impaired phosphate metabolism has been incompletely studied to date, and more detailed investigations are required to fully characterize this potential pathogenic condition.

\section{Phosphate and Renal Disease Progression}

The association between serum phosphate levels and deterioration of renal function was previously explained by the 'precipitation-calcification hypothesis' speculating that phosphate which is absorbed in excess of residual nephron excretory capacity leads to the deposition of calcium-phosphate crystals in the mitochondria of tubular cells, renal interstitium, peritubular space and capillaries. This may induce an inflammatory process and cell damage, resulting in interstitial fibrosis and tubular atrophy $[55,56]$. In the light of these studies, dietary phosphorus restriction may prevent the progression of renal failure independent of protein and calorie intake. Conversely, diets high in phosphorus content may result in a more rapid deterioration of renal function independent of protein and calorie intake.

Recent studies have shown that patients with hyperphosphatemia had a rapid decline in renal function and a higher mortality during the predialysis period $[26,28$, $55,57,58]$. Moreover, high phosphate intake contributed to the loss of residual renal function in CKD [58]. These data are further supported by an experimental study by Koizumi et al. [55] investigating the effect of dietary phosphate on the prognosis of CKD. Regular diet, normal cow's milk and low-phosphate-containing milk were given to 5/6 nephrectomized rats. At the end of the study, while serum phosphate levels did not differ among groups, the serum creatinine level was significantly lower in the rats fed low-phosphate-containing milk. The authors speculated that higher dietary phosphate intake may have played a major role in the loss of kidney function in CKD and lower phosphate intake might have delayed the progression of kidney dysfunction in CKD [57].

If the above findings are correct, the medical community is challenged very considerably. The 'upper limit of acceptable plasma phosphate' may need to be revised. Possibly, the optimal cutoff level for phosphate is $<1.0$ $(<3.0 \mathrm{mg} / \mathrm{dl}) \mathrm{mmol} / \mathrm{l}$, but interventional trials are needed to show that a reduction in plasma phosphate levels in CKD patients may lead to an improvement in the course of CVD and renal disease. Plasma phosphate levels are subjected to dietary control at this early stage of CKD, and control often starts when plasma phosphate levels are borderline increased. The more liberal use of orally active 
phosphate binders or inhibitors of phosphate absorption across the bowel wall also needs to be tested for tolerability, efficacy and outcome.

\section{Conclusion}

Although these observational data do not lead to the definite conclusion that phosphate is a major risk factor for cardiorenal disease in subjects with normal kidney function, all of these diverse studies strongly suggest that hyperphosphatemia is a veritable stealthy 'vascular toxin' - an insidious 'bone maker' in the walls of blood vessels, a promoter of premature aging even in subjects with normal kidney function, and a factor which causes more rapid decline in kidney function in patients with CKD. Loss of phosphate control can perhaps trigger the cardiorenal syndrome - hitting the $\mathrm{CV}$ system harder than the renal one in terms of a poor outcome, as so many patients may die in CKD of CV disease and before reaching dialysis. Future studies focusing on phosphate and clinical outcomes should also measure serum PTH and 1,25-dihydroxy vitamin D levels, and assess other bone and di- etary factors at the same time in the same patients to explore whether or not potential associations between phosphate and CV risk levels are independent of these other tightly linked parameters. Of note, the lack of any clear association between plasma calcium and CKD or CV outcomes in these CKD studies is in marked contrast to studies on dialysis patients, in whom plasma calcium is more likely to be affected by drug therapy for phosphate binding.

Elevated phosphate levels may yet turn out to be much more potent, and more prevalent (by a redefinition of acceptable upper limits of normal), in its effect on CVD in patients with mild-to-moderate CKD - it may be that 'phosphate' is the renal patients' 'cholesterol' when comparing ischemic heart disease in the non-CKD setting. Consequently, a reexamination of our existing approaches to even mildly elevated serum phosphate levels would be urgently needed.

In conclusion, subject to further studies confirming that a reduction in marginally elevated plasma phosphate levels can reduce cardiorenal event rates, earlier and more effective phosphate control is the key to successful management of CKD patients.

\section{References}

$>1$ Brown JH, Hunt LP, Vites NP, Short CD, Gokal R, Mallick NP: Comparative mortality from cardiovascular disease in patients with chronic renal failure. Nephrol Dial Transplant 1994;9:1136-1142.

-2 Keith DS, Nichols GA, Gullion CM, Brown JB, Smith DH: Longitudinal follow-up and outcomes among a population with chronic kidney disease in a large managed care organization. Arch Intern Med 2004;164:659-663.

$\checkmark 3$ Vanholder R, Meert N, Schepers E, Glorieux G: Uremic toxins: do we know enough to explain uremia? Blood Purif 2008;26:77-81.

$\checkmark 4$ Covic A, Gusbeth-Tatomir P, Goldsmith D: Negative outcome studies in end-stage renal disease: how dark are the storm clouds? Nephrol Dial Transplant 2008;23:56-61.

$\checkmark 5$ Foley RN, Parfrey PS, Sarnak MJ: Clinical epidemiology of cardiovascular disease in chronic renal disease. Am J Kidney Dis 1998; 32(5 suppl 3):S112-S119.

$\checkmark 6$ Sarnak MJ, Levey AS: Cardiovascular disease and chronic renal disease: a new paradigm. Am J Kidney Dis 2000;35(4 suppl 1): S117-S131.

7 Goodman WG, Goldin J, Kuizon BD, Yoon C, Gales B, Sider D, Wang Y, Chung J, Emerick A, Greaser L, Elashoff RM, Salusky IB: Coronary-artery calcification in young adults with end-stage renal disease who are undergoing dialysis. N Engl J Med 2000;342: 1478-1483.
-8 Blacher J, Guerin AP, Pannier B, Marchais SJ, London GM: Arterial calcifications, arterial stiffness, and cardiovascular risk in endstage renal disease. Hypertension 2001;38: 938-942.

$\checkmark 9$ Jono S, McKee MD, Murry CE, Shioi A Nishizawa Y, Mori K, Morii H, Giachelli CM: Phosphate regulation of vascular smooth muscle cell calcification. Circ Res 2000;87: E10-E17.

10 Block GA, Hulbert-Shearon TE, Levin NW, Port FK: Association of serum phosphorus and calcium $\mathrm{x}$ phosphate product with mortality risk in chronic hemodialysis patients: a national study. Am J Kidney Dis 1998;31: 607-617.

-11 Block GA, Klassen PS, Lazarus JM, Ofsthun N, Lowrie EG, Chertow GM: Mineral metabolism, mortality, and morbidity in maintenance hemodialysis. J Am Soc Nephrol 2004; 15:2208-2218.

12 Stevens LA, Djurdjev O, Cardew S, Cameron EC, Levin A: Calcium, phosphate, and parathyroid hormone levels in combination and as a function of dialysis duration predict mortality: evidence for the complexity of the association between mineral metabolism and outcomes. J Am Soc Nephrol 2004;15: 770-779.

13 Young EW, Albert JM, Satayathum S, Goodkin DA, Pisoni RL, Akiba T, Akizawa T, Kurokawa K, Bommer J, Piera L, Port FK: Pre- dictors and consequences of altered mineral metabolism: the Dialysis Outcomes and Practice Patterns Study. Kidney Int 2005;67: 1179-1187.

14 Noordzij M, Korevaar JC, Dekker FW, Boeschoten EW, Bos WJ, Krediet RT, Bossuyt PM, Geskus RB; NECOSAD study group: Mineral metabolism and mortality in dialysis patients: a reassessment of the K/DOQI guideline. Blood Purif 2008;26:231-237.

15 Matsubara K, Suliman ME, Qureshi AR, Axelsson J, Martola L, Heimbürger O, Barany $\mathrm{P}$, Stenvinkel P, Lindholm B: Bone mineral density in end-stage renal disease patients: association with wasting, cardiovascular disease and mortality. Blood Purif 2008;26:284-290.

16 Covic A, Gusbeth-Tatomir P, Goldsmith DJ: Vascular calcification - a new window on the cardiovascular system: role of agents used to manipulate skeletal integrity. Semin Dial 2007;20:158-169.

17 Weiner DE, Tighiouart H, Elsayed EF, Griffith JL, Salem DN, Levey AS, Sarnak MJ: The relationship between nontraditional risk factors and outcomes in individuals with stage 3 to 4 CKD. Am J Kidney Dis 2008; 51:212-223.

18 Hayden JA, Côté P, Bombardier C: Evaluation of the quality of prognosis studies in systematic reviews. Ann Intern Med 2006;144: 427-437. 
-19 Narang R, Ridout D, Nonis C, Kooner JS: Serum calcium, phosphorus and albumin levels in relation to the angiographic severity of coronary artery disease. Int J Cardiol 1997; 60:73-79.

-20 Zittermann A, Schleithoff SS, Tenderich G, Berthold HK, Körfer R, Stehle P: Low vitamin D status: a contributing factor in the pathogenesis of congestive heart failure? J Am Coll Cardiol 2003;41:105-112.

-21 Tonelli M, Sacks F, Pfeffer M, Gao Z, Curhan G; Cholesterol and Recurrent Events Trial Investigators: Relation between serum phosphate level and cardiovascular event rate in people with coronary disease. Circulation 2005;112:2627-2633.

$\checkmark 22$ Kestenbaum B, Sampson JN, Rudser KD, Patterson DJ, Seliger SL, Young B, Sherrard DJ, Andress DL: Serum phosphate levels and mortality risk among people with chronic kidney disease. J Am Soc Nephrol 2005;16: 520-528.

-23 Dhingra R, Sullivan LM, Fox CS, Wang TJ, D’Agostino RB Sr, Gaziano JM, Vasan RS: Relations of serum phosphorus and calcium levels to the incidence of cardiovascular disease in the community. Arch Intern Med 2007; 167:879-885

-24 Onufrak SJ, Bellasi A, Shaw LJ, Herzog CA, Cardarelli F, Wilson PW, Vaccarino V, Raggi P: Phosphorus levels are associated with subclinical atherosclerosis in the general population. Atherosclerosis 2008;199:424-431.

-25 Kovesdy CP, Ahmadzadeh S, Anderson JE, Kalantar-Zadeh K: Secondary hyperparathyroidism is associated with higher mortality in men with moderate to severe chronic kidney disease. Kidney Int 2008;73:12961302.

-26 Kanbay M, Isik B, Akcay A, Ozkara A, Karakurt F, Turgut F, Alkan R, Uz E, Bavbek N, Yigitoglu R, Covic A: Relation between serum calcium, phosphate, parathyroid hormone and 'nondipper' circadian blood pressure variability profile in patients with normal renal function. Am J Nephrol 2007; 27:516-521.

-27 Menon V, Greene T, Pereira AA, Wang X, Beck GJ, Kusek JW, Collins AJ, Levey AS, Sarnak MJ: Relationship of phosphorus and calcium-phosphorus product with mortality in CKD. Am J Kidney Dis 2005;46:455-463.

28 Voormolen N, Noordzij M, Grootendorst DC, Beetz I, Sijpkens YW, van Manen JG, Boeschoten EW, Huisman RM, Krediet RT, Dekker FW; PREPARE study group: High plasma phosphate as a risk factor for decline in renal function and mortality in pre-dialysis patients. Nephrol Dial Transplant 2007; 22:2909-2916.

29 Hsu CY, Chertow GM: Elevations of serum phosphorus and potassium in mild to moderate chronic renal insufficiency. Nephrol Dial Transplant 2002;17:1419-1425.

-30 Schwarz S, Trivedi BK, Kalantar-Zadeh K, Kovesdy CP: Association of disorders in mineral metabolism with progression of chronic kidney disease. Clin J Am Soc Nephrol 2006;1:825-831.
31 Hruska K, Slatopolsky E: Disorders of phosphorus, calcium, and magnesium; in Schrier R, Gottschalk C (eds): Diseases of the Kidney. London, Little, Brown, 1996, vol 3, pp 2477-2526.

32 Klahr S: The Kidney and Body Fluids in Health and Disease. New York, Plenum, 1983.

33 Bowe AE, Finnegan R, Jan de Beur SM, Cho J, Levine MA, Kumar R, Schiavi SC: FGF-23 inhibits renal tubular phosphate transport and is a PHEX substrate. Biochem Biophys Res Commun 2001;284:977-981.

34 Chen NX, O’Neill KD, Duan D, Moe SM: Phosphorus and uremic serum up-regulate osteopontin expression in vascular smooth muscle cells. Kidney Int 2002;62:1724-1731.

35 Moe SM, Chen NX: Mechanisms of Vascular calcification in chronic kidney disease. J Am Soc Nephrol 2008;19:213-216.

36 Giachelli CM: Vascular calcification: in vitro evidence for the role of inorganic phosphate. J Am Soc Nephrol 2003;14(9 suppl 4):S300S304.

-37 Neves KR, Graciolli FG, dos Reis LM, Pasqualucci CA, Moysés RM, Jorgetti V: Adverse effects of hyperphosphatemia on myocardial hypertrophy, renal function, and bone in rats with renal failure. Kidney Int 2004;66:2237-2244.

38 Amann K, Törnig J, Kugel B, Gross ML, Tyralla K, El-Shakmak A, Szabo A, Ritz E: Hyperphosphatemia aggravates cardiac fibrosis and microvascular disease in experimental uremia. Kidney Int 2003;63:1296-1301.

39 Amann K, Ritz E, Wiest G, Klaus G, Mall G: A role of parathyroid hormone for the activation of cardiac fibroblasts in uremia. J Am Soc Nephrol 1994;4:1814-1819.

40 Grey A, Mitnick MA, Masiukiewicz U, Sun BH, Rudikoff S, Jilka RL, Manolagas SC, Insogna K: A role for interleukin- 6 in parathyroid hormone-induced bone resorption in vivo. Endocrinology 1999;140:4683-4690.

41 Mitnick MA, Grey A, Masiukiewicz U, Bartkiewicz M, Rios-Velez L, Friedman S, Xu L, Horowitz MC, Insogna K: Parathyroid hormone induces hepatic production of bioactive interleukin- 6 and its soluble receptor. Am J Physiol Endocrinol Metab 2001;280: E405-E412.

42 Kuro-o M, Matsumura Y, Aizawa H, et al: Mutation of the mouse klotho gene leads to a syndrome resembling ageing. Nature 1997; 390:45-51.

43 Tsujikawa H, Kurotaki Y, Fujimori T, Fukuda K, Nabeshima Y: Klotho, a gene related to a syndrome resembling human premature aging, functions in a negative regulatory circuit of vitamin D endocrine system. Mol En docrinol 2003; 17:2393-2403.

44 Shimada T, Kakitani M, Yamazaki Y, et al: Targeted ablation of Fgf23 demonstrates an essential physiological role of FGF23 in phosphate and vitamin D metabolism. J Clin Invest 2004;113:561-568.
45 Morishita K, Shirai A, Kubota M, Katakura Y, Nabeshima Y, Takeshige K, Kamiya T: The progression of aging in klotho mutant mice can be modified by dietary phosphorus and zinc. J Nutr 2001;131:3182-3188.

46 Taketani Y, Shuto E, Arai H, Nishida Y, Tanaka R, Uebanso T, Yamamoto H, Yamanaka-Okumura H, Takeda E: Advantage of a low glycemic index and low phosphate diet on diabetic nephropathy and aging-related diseases. J Med Invest 2007;54:359365 .

47 Yamamoto M, Clark JD, Pastor JV, Gurnani P, Nandi A, Kurosu H, Miyoshi M, Ogawa Y, Castrillon DH, Rosenblatt KP, Kuro-o M: Regulation of oxidative stress by the anti-aging hormone klotho. J Biol Chem 2005;280: 38029-38034.

48 Chan CT, Wells H, Kramsch DM: Suppression of calcific fibrous-fatty plaque formation in rabbits by agents not affecting elevated serum cholesterol levels. The effect of thiophene compounds. Circ Res 1978;43: 115-125.

49 Portale AA, Halloran BP, Morris RC Jr: Physiologic regulation of the serum concentration of 1,25-dihydroxyvitamin D by phosphorus in normal men. J Clin Invest 1989;83: 1494-1499.

50 Scragg R, Jackson R, Holdaway IM, Lim $\mathrm{T}$, Beaglehole R: Myocardial infarction is inversely associated with plasma 25-hydroxyvitamin D3 levels: a community-based study. Int J Epidemiol 1990;19:559-563.

-51 Brunvand L, Hågå P, Tangsrud SE, Haug E: Congestive heart failure caused by vitamin D deficiency? Acta Paediatr 1995;84:106-108.

52 Watson KE, Abrolat ML, Malone LL, Hoeg JM, Doherty T, Detrano R, Demer LL: Active serum vitamin D levels are inversely correlated with coronary calcification. Circulation 1997;96:1755-1760.

53 Hedbäck G, Odén A: Increased risk of death from primary hyperparathyroidism - an update. Eur J Clin Invest 1998;28:271-276.

54 Nishida Y, Taketani Y, Yamanaka-Okumura H, Imamura F, Taniguchi A, Sato T, Shuto E, Nashiki K, Arai H, Yamamoto H, Takeda E: Acute effect of oral phosphate loading on serum fibroblast growth factor 23 levels in healthy men. Kidney Int 2006;70:2141-2147.

55 Koizumi T, Murakami K, Nakayama H, Kuwahara T, Yoshinari Ohnishi: Role of dietary phosphorus in the progression of renal failure. Biochem Biophys Res Commun 2002; 295:917-921

56 Lau K: Phosphate excess and progressive renal failure: the precipitation-calcification hypothesis. Kidney Int 1989;36:918-937.

57 Loghman-Adham M: Role of phosphate retention in the progression of renal failure. $J$ Lab Clin Med 1993;122:16-26.

58 Maschio G, Oldrizzi L, Tessitore N, D’Angelo A, Valvo E, Lupo A, Loschiavo C, Fabris A, Gammaro L, Rugiu C, et al: Early dietary protein and phosphorus restriction is effective in delaying progression of chronic renal failure. Kidney Int Suppl 1983;16:S273S277. 